\title{
Validity of Serum Uromodulin as Early Diagnosis Marker of Diabetic Nephropathy in T2DM
}

\author{
Rizki Dumpatna, Nina Tristina, Dewi Kartika Turbawaty, Anna Tjandrawati \\ Department of Clinical Pathology Faculty of Medicine Universitas Padjadjaran \\ Dr. Hasan Sadikin General Hospital Bandung, Indonesia
}

\begin{abstract}
Increased prevalence of DM is accompanied by increased in its various complications include diabetic nephropathy, which can lead to end stage renal disease (ESRD). Urinary albumin-creatinine ratio (uACR) is the gold standard for diabetic nephropathy; however, it has several limitations, including the inability to early diagnose due to the absence of increased level in uACR. Uromodulin is produced by thick ascending limb (TAL) at Henle's loop and early distal tubule of nephron. Uromodulin will decrease when tubular atrophy occurs in early stage of renal impairment with normoalbuminuria. The aim of this study was to determine the validity of serum uromodulin in type 2 diabetes mellitus (T2DM) in identifying diabetic nephropathy by comparing it with uACR as gold standard. This study was a cross-sectional analytical observational study at Dr. Hasan Sadikin (RSHS) Bandung from June to August 2020. Subjects consisted of 62 patiens with T2DM. Results showed that the serum uromodulin level had a sensitivity of $93.3 \%$, a specificity of $88.2 \%$, a positive predictive value of $95.5 \%$, a negative predictive value of $83.3 \%$, and an accuracy of $91,9 \%$ and an AUC value of 0.975 . The cut-off point of serum uromodulin in this study was $47.195 \mathrm{ng} / \mathrm{mL}$. In conclusion, serum uromodulin, when compared to the uACR as the gold standard, has good sensitivity and specificity for identifying diabetic nephropathy.
\end{abstract}

Keywords: Albuminuria, diabetes mellitus type 2 (T2DM), diabetic nephropathy, urinary albumin-creatinine ratio (uACR), serum uromodulin

\section{Validitas Uromodulin Serum Sebagai Penanda Diagnosis Dini Nefropati Diabetes Pada Diabetes Melitus Tipe 2}

\begin{abstract}
Abstrak
Peningkatan prevalensi DM diiringi dengan peningkatan komplikasi yang ditimbulkan, salah satunya adalah nefropati diabetes yang dapat berakhir menjadi end stage renal disease (ESRD). Pemeriksaan urinary albumincreatinine ratio (UACR) memiliki keterbatasan mendiagnosis gangguan fungsi ginjal tahap awal, disebabkan belum terjadinya peningkatan kadar albumin urine, serta sebagian besar gangguan ginjal pada pasien DM terjadi pada keadaan normoalbuminuria. Uromodulin diproduksi oleh sel-sel epitel yang melapisi thick ascending limb (TAL) di loop of Henle dan tubulus distal, kadar uromodulin menurun saat atrofi tubulus pada tahap awal gangguan fungsi ginjal. Tujuan penelitian ini adalah menganalisis validitas uromodulin serum sebagai penanda diagnosis dini nefropati diabetes pada T2DM dengan baku emas uACR. Penelitian ini analitik observasional deskriptif khusus dengan rancangan penelitian potong lintang yang dilakukan di RSUP Dr. Hasan Sadikin Bandung pada bulan Juni-Agustus 2020. Subjek penelitian adalah 62 penderita T2DM dari Poliklinik Endokrin RSUP Dr. Hasan Sadikin Bandung. Hasil uji validitas pada penelitian ini menunjukkan sensitivitas 93,3\%, spesifisitas 88,2\%, nilai duga positif 95,5\%, nilai duga negatif 83,3\%, akurasi 91,9\% serta nilai area under the curve (AUC) $0,975$. cut-off point uromodulin serum penelitian ini sebesar 47,195 ng/mL. Kesimpulan dari penelitian ini, validitas pemeriksaan kadar uromodulin serum terhadap baku emas uACR memiliki sensitivitas dan spesifisitas yang baik.
\end{abstract}

Kata kunci: Albuminuria, diabetes melitus tipe 2 (T2DM), nefropati diabetes, urinary albumin-creatinine ratio (uACR), uromodulin serum

Corresponding Author: Rizki Dumpatna, Department of Clinical Pathology Faculty of Medicine Universitas Padjadjaran / Dr. Hasan Sadikin General Hospital Bandung, Jalan Pasteur No. 38 Bandung, West Java, Indonesia, Email: drizkidumpatna.2308@ gmail.com 


\section{Introduction}

Chronic kidney disease (CKD) is a disease that involves reduced kidney function with diabetes mellitus (DM) as the most common risk and the most prevalent comorbidity. Diabetes mellitus itself is a condition caused by metabolic disorders due to pancreas being unable to produce hormone insulin adequately or when the body unable to use insulin effectively, resulting in increased blood glucose level. ${ }^{1}$ According to the Centers of Disease Control Prevention (CDC) in 2019 , DM is responsible for $38 \%$ of end stage renal disease (ESRD) incidence. In addition, about $20 \%$ of type 1 diabetes mellitus (T1DM) or type 2 diabetes mellitus (T2DM) will develop into diabetic nephropathy in years. Diabetic nephropathy is a microvascular complication and is the main cause of end stage renal disease (ESRD). Long-term diabetes may cause impaired nephron functions due to structural changes, such as focal tubular atrophy, thickening of basement membrane in glomerulus and tubular, and expansion of mesangial cells accompanied by increased matrix (glomerulosclerosis). ${ }^{2}$

In daily clinical practice, albuminuria is considered as a sign of the early development of diabetic nephropathy. ${ }^{3}$ Currently, few studies have shown that diabetic patients may still experience decreased kidney function due to diabetic nephropathy without changes in urine albumin levels or normoalbuminuria. It is demonstrated that 30\% -50\% type 2 Diabetes Mellitus (T2DM) patients may regress to normoalbuminuria although they experience impaired kidney function. ${ }^{4}$

Biological markers currently used in daily clinical practice to evaluate diabetic nephropathy and decreased renal function include serum creatinine, urea, proteinuria, and albuminuria. ${ }^{5}$ However, laboratory tests such as serum creatinine and measurement of glomerular filtration rate (GFR) may only depict changes in kidney function over a long period of time or if $50 \%$ of nephrons have experienced damages. ${ }^{6,7}$ Meanwhile, detecting albuminuria can be undertaken using the urinary albumincreatinine ratio (uACR) from random urine sample (urine spot). ${ }^{8}$ According to the American Diabetes Association (ADA) and the Indonesian Endocrinologist Society (Perkumpulan Endokrinologi Indonesia, PERKENI) in 2015, uACR is the gold standard for diagnosing diabetic kidney disease. This examination has a better predictive value than other parameters. ${ }^{9}$

To date, few studies have focused on strategies to develop biological markers that may overcome limitations of albuminuria and clinically useful for early detection of diabetic nephropathy or those that develop CKD. ${ }^{3}$ One of them is uromodulin or Tamm-Horsfall protein, which is synthesized exclusively by thick ascending limb (TAL) epithelial cells of the loop of Henle and the distal tubule. The protein reaches renal interstitium and presents in serum at very low level (70$540 \mathrm{ng} / \mathrm{mL}$ ). Compared to other biological markers of tubular damage, uromodulin is an independent, sensitive and predictive biological marker for renal tubular function and can detect the risk of developing diabetic nephropathy early. ${ }^{10}$ In addition, previous studies have shown that serum uromodulin level are positively correlated with eGFR and negatively correlated with urinary albumin level. ${ }^{11}$

The validity test denotes the ability of an examination to distinguish people with and without disease. The validity test includes sensitivity, specificity, accuracy, positive predictive value, and negative predictive value. ${ }^{11}$ The aim of this study was to examine the validity of uromodulin examination, so that it may be used as an early diagnostic tool for diabetic nephropathy in the future.

\section{Methods}

This study was a cross-sectional observational analytic study conducted in June-August 2020 on male and female patients diagnosed with type 2 diabetes mellitus (T2DM) according to the PERKENI criteria by clinicians at the Endocrine Clinic of Dr. Hasan Sadikin General Hospital Bandung, Indonesia, with an eGFR of $60-\geq 90$ $\mathrm{mL} / \mathrm{min} / 1.73 \mathrm{~m}^{2}$. The exclusion criteria were patients with urinary tract infection; athletes; smokers; patients taking losartan, fenofibrate and ruboxistaurin; hemolysis, lipemic and icteric blood sample; and insufficient urine sample.

A total $2 \mathrm{~mL}$ Blood was collected by phlebotomy on the cubital vein, while urine used was \pm $10 \mathrm{~mL}$ mid-stream urine from random urine. Examination of serum uromodulin level was carried out using the Sandwich ELISA method. Serum creatinine level was measured using the kinetic Jaffe method. The material was stable serum at $2-8^{\circ} \mathrm{C}$ for 7 days, stable at $-20^{\circ} \mathrm{C}$ less than 1 month, and stable at $-80^{\circ} \mathrm{C}$ less than 3 months. After obtaining serum creatinine result, eGFR was calculated. Examination of the uACR level used Meditape II 10K strip test with a semiquantitative method. Materials were examined at 
the Central Laboratory of the Clinical Laboratory Installation of Dr. Hasan Sadikin General Hospital, Bandung, Indonesia. Sampling was done by consecutive sampling. The sensitivity value in this study was set at $50 \%(0.5 \%)$ and the sample size for this diagnostic test was calculated using the following formula:

$$
\mathrm{n}=\frac{{ }_{\alpha}^{\mathrm{z}} / 2 \text { sens }-(1-\text { sens })}{\mathrm{d}^{2} \mathrm{P}}
$$

Notes:

$\mathrm{n} \quad=$ Number of subjects

$\mathrm{Z} \alpha / 2=\mathrm{Z}$ value from normal distribution Table for $95 \%$ confidence interval $(\mathrm{Z}=1.96)$

Sen $=$ Uromodulin sensitivity value to eGFR $(80 \%=0.80)$

$\mathrm{d}=\quad=$ Study precision $(20 \%)$

$\mathrm{P} \quad=$ Study prevalence $(40 \%)^{12}$

Number of samples required based on sample formula to uACR was:

$$
\begin{aligned}
& \mathrm{n}=\frac{(1.96)^{2} * 0.5 * 0.5}{(0.2)^{2 * 0.40}} \\
& \mathrm{n}=\frac{3.8416 \times 0.25}{0.04 \times 0.4} \\
& \mathrm{n}=60
\end{aligned}
$$

To anticipate data loss, additional samples of $10 \%$ of the sample size was added, leading to a minimum sample size of $60+6=66$.

The normality test used for a sample size of more than 50 subjects was performed using the Kolmogorov Smirnov test, while for the size of less than 50, the Shapiro Wilk's test was selected. Normality test was declared to be normally distributed if $\mathrm{p}>0.05$. For normally distributed data, a parametric analysis was performed using the unpaired t test while for those that were not normally distributed, non-parametric data analyses using the Mann Whitney's test and Chi square were performed. Data were analyzed using the SPSS for windows version 26.0 program at $95 \%$ confidence interval, and results were deemed to be statistically significant if $\mathrm{p}<0.05$. The uromodulin data obtained were analyzed using the ROC curve to obtain a cut-off value for the diagnosis of diabetic nephropathy and calculate the area under the curve (AUC). This was then followed by an analysis on the validity value to uACR gold standard. ${ }^{24}$ This study was approved by the Health Research Ethics Committee of Dr. Hasan Sadikin General Hospital Bandung through the issuance of the ethical approval no. LB.02.01/X.6.5/183/2020.

\section{Results}

A total of 71 people with T2DM diagnosed using the PERKENI criteria by clinicians at the Endocrine Clinic of Dr. Hasan Sadikin General Hospital, Bandung, Indonesia participated in this study. A total of 9 people were excluded due to insufficient urine sample for the uACR examination. The number of subjects in this study who met the inclusion and exclusion criteria and were willing took part in the study by signing the informed consent form was 62 .

The characteristics of subjects based on sex, age, BMI category, duration of diabetes, and eGFR calculation result are shown in Table 1. In the Table, subjects are further classified into normoalbuminuria (uACR level $<30 \mathrm{mg} / \mathrm{gCr}$ ) and albuminuria (uACR level $>30 \mathrm{mg} / \mathrm{gCr}$ ).

From Table 1 above, 10 males were in the albuminuria group (58.8\%), and 28 women were in the same group (62.2\%). The mean age of the participants was \pm 63 years, and the BMI categories ranged from normal to overweight. The majority of participants had been suffering from diabetes for less than 5 years. The mean serum uromodulin level in normoalbuminuria group was two times higher than that of the albuminuria group.

Table 2 shows the sensitivity and specificity

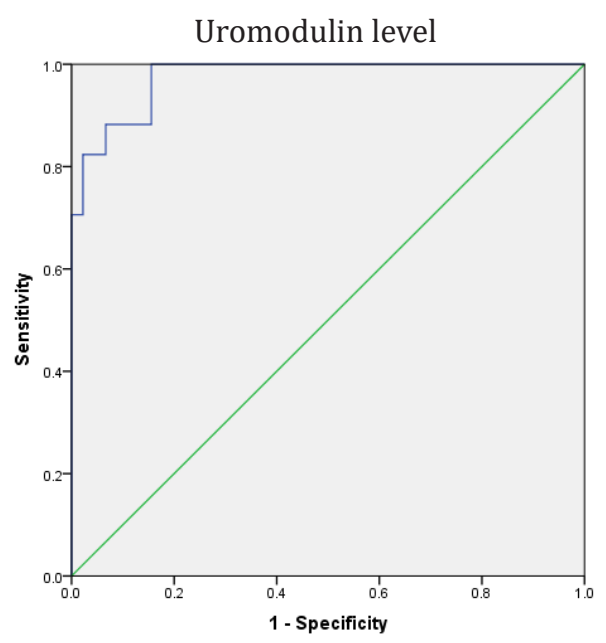

Figure ROC Curve of Serum Uromodulin Level 
R Dumpatna et al.: Validity of Serum Uromodulin as Early Diagnosis Marker of Diabetic Nephropathy in T2DM

Table 1 Subject Characteristics

\begin{tabular}{|c|c|c|c|c|}
\hline \multirow[b]{2}{*}{ Characteristics } & \multirow[b]{2}{*}{ Total $(n=62)$} & \multicolumn{2}{|c|}{ T2DM Group } & \multirow[b]{2}{*}{ p value } \\
\hline & & $\begin{array}{c}\text { Normoalbuminuria } \\
n=17(\%)\end{array}$ & $\begin{array}{c}\text { Albuminuria } \\
n=45(\%)\end{array}$ & \\
\hline \multicolumn{5}{|l|}{ Sex } \\
\hline Male & 27 & $10(58.8 \%)$ & $17(37.8 \%)$ & $0.136^{\mathrm{a}}$ \\
\hline Female & 35 & $7(41.2 \%)$ & $28(62.2 \%)$ & \\
\hline \multicolumn{5}{|l|}{ Age (years) } \\
\hline Mean \pm SD & & $55.82 \pm 11.82$ & $60.84 \pm 12,696$ & $0.163^{\mathrm{b}}$ \\
\hline Median & & 52 & 63 & \\
\hline Range (Min-Max) & & $40-80$ & $33-80$ & \\
\hline BMI category $\left(\mathrm{kg} / \mathrm{m}^{2}\right)$ & & & & $0.850^{\mathrm{c}}$ \\
\hline Underweight & & 0 & $4(8.9 \%)$ & \\
\hline Normal & & $8(47.1 \%)$ & $25(55.6 \%)$ & \\
\hline Overweight & & $7(41.2 \%)$ & $16(35.6 \%)$ & \\
\hline Obesity & & $2(11.8 \%)$ & 0 & \\
\hline Duration of DM (years) & & & & $0.445^{\mathrm{c}}$ \\
\hline$<1$ year & & $5(29.4 \%)$ & $9(20 \%)$ & \\
\hline $1-5$ years & & $9(52.9 \%)$ & $17(37.8 \%)$ & \\
\hline $5-10$ years & & $2(11.8 \%)$ & $11(24.4 \%)$ & \\
\hline >10 years & & $1(5.9 \%)$ & $8(17.8 \%)$ & \\
\hline $\mathrm{uACR}(\mathrm{mg} / \mathrm{g}) \mathrm{Cr}$ & & & & $0.0001^{c^{*}}$ \\
\hline Mean \pm SD & & 30 & $271.11 \pm 161,839$ & \\
\hline Median & & - & 200 & \\
\hline Range (Min-Max) & & - & $100-500$ & \\
\hline eGFR (ml / min / 1.73m2) & & & & $0.017^{\mathrm{c}^{*}}$ \\
\hline Mean \pm SD & & $89.82 \pm 14,732$ & $79.07 \pm 17,961$ & \\
\hline Median & & 87.6 & 71.4 & \\
\hline Range (Min-Max) & & $64-122.7$ & $60-123.6$ & \\
\hline
\end{tabular}

a: Chi-Square test; b: unpaired T test; c: Mann Whitney test; *means $\mathrm{p}<0.05$; significant or statistically significant

Table 2 Sensitivity and Specificity Values of Serum Uromodulin Level From Various Cutoff Values

\begin{tabular}{ccc}
\hline Uromodulin cut-off value (ng / mL) & Sensitivity (\%) & Specificity (\%) \\
\hline$<44,9231$ & 84.4 & 94.1 \\
$<45,5649$ & 84.4 & 88.2 \\
$<46,2856$ & 86.7 & 88.2 \\
$<46,5799$ & 88.9 & 88.2 \\
$<46,9242$ & 91.1 & 88.2 \\
$\leq 47,195$ & 93.3 & 88.2 \\
$<47.5194$ & 93.3 & 82.4 \\
$<48.1335$ & 95.6 & 82.4 \\
$<50,5041$ & 97.8 & 82.4 \\
$<55.5209$ & 97.8 & 70.6 \\
$<62,6023$ & 100 & 70.6 \\
\hline
\end{tabular}


Table 3 Validity of Serum Uromodulin Level Examination with uACR as Gold Standard

\begin{tabular}{lcccc}
\hline & \multicolumn{2}{c}{ T2DM } & Total \\
\cline { 2 - 4 } & & $\begin{array}{c}\text { Albuminuria } \\
(\mathbf{n = 4 5 )}\end{array}$ & $\begin{array}{c}\text { Normoalbuminur } \\
(\mathbf{n = 1 7})\end{array}$ & $\begin{array}{c}\text { (n) } \\
\text { Uromodulin }(\mathrm{ng} / \mathrm{mL})\end{array}$ \\
& $\leq 47,195$ & 42 & 2 & 44 \\
& $>47,195$ & 3 & 15 & 18 \\
\hline
\end{tabular}

Note: Sensitivity = a / $(\mathrm{a}+\mathrm{c})=42 / 45 \times 100 \%=93.3 \%$; Specificity = d / $(\mathrm{b}+\mathrm{d})=15 / 17 \times 100 \%=88.2 \%$; Positive Predictive Value $=\mathrm{a} /(\mathrm{a}+\mathrm{b})=42 / 44 \times 100 \%=95.5 \%$; Negative Predictive Value $=\mathrm{d} /(\mathrm{c}+\mathrm{d})=15 / 18 \times 100 \%=83.3 \%$; Accuracy $=(\mathrm{a}+\mathrm{d}) / \mathrm{N}=57 / 62 \times 100 \%=91.9 \%$

values of serum uromodulin level of various cutoff value. The cut-off value used in this study was 47.195 with sensitivity and specificity values of $93.3 \%$ and $88.2 \%$, respectively.

Figure depicts the ROC curve of the serum uromodulin level. From the cut-off value of 47.2, the area under the curve (AUC) was found to be $97.5 \%$. Referring to the categories of diagnostic value, in the serum uromodulin level was categorized into a very strong diagnostic indicator.

In Table 3, the sensitivity and specificity values obtained were $93.3 \%$ and $88.2 \%$, respectively. The sensitivity value indicated a $93.3 \%$ possibility that serum uromodulin level yielded low result in T2DM subjects with albuminuria. While the specificity value indicated a $88.2 \%$ possibility that serum uromodulin level will yielded a high result in T2DM subjects with normoalbuminuria. The positive predictive value was $95.5 \%$, meaning that there was a $95.5 \%$ possibility that the T2DM patients would experience diabetic nephropathy (albuminuria) if the serum uromodulin level was more than $47.2 \mathrm{ng} / \mathrm{mL}$. A negative predictive value of $83.3 \%$ demonstrated a $83.3 \%$ possibility that a person would not experience diabetic nephropathy (normoalbuminuria) if the serum uromodulin level was more than $47.2 \mathrm{ng} / \mathrm{mL}$. The calculation on the accuracy in this study yielded an accuracy of $91.9 \%$.

\section{Discussion}

This study found that most of subjects had experienced T2DM for less than 5 years. This was consistent with a study conducted by Alfehaid et al. stating that there was a statistically significant correlation regarding the duration of T2DM with albuminuria. In addition, T2DM is associated with the development of diabetic nephropathy complications; therefore, the ADA recommends
uACR for all T2DM patients at first diagnosis. ${ }^{13}$

The present study showed that there was a significant difference in the median uromodulin level in T2DM albuminuria group (33.45 ng/ $\mathrm{mL}$ ) and normoalbuminuria group (75.51 ng/ $\mathrm{mL}$ ). Uromodulin is produced exclusively in the kidney by the epithelial cells of thick ascending limb (TAL) of Henle's loop and distal tubule. Low serum uromodulin levels are associated with structural disorders of TAL. ${ }^{10}$ In T2DM, metabolic changes, such as hyperglycemia, occur, which will cause the tubular cells to experience hyperplasia and hypertrophy and will stimulate interstitial inflammation resulting in interstitial fibrosis and tubular atrophy. ${ }^{6,7}$ Damages in the tubules occur earlier than in the glomerulus as diabetic nephropathy develops. Reduced serum uromodulin level is seen in the early stage of diabetic nephropathy. ${ }^{4}$ A previous study has also stated that a decline in the uromodulin level is found to be significant in the T2DM group with albuminuria. This could be due to the level of glycemic control associated with changes in the renal tubular function that occur in the early stages of DM. ${ }^{14}$

The uromodulin level has an inverse correlation with CKD stage; thus, the higher the CKD stage is, the lower the uromodulin level..$^{15} \mathrm{In}$ Table 4 , the cut-off value of the serum uromodulin level is shown to be $47.2 \mathrm{ng} / \mathrm{mL}$ with a sensitivity of $93.3 \%$ and a specificity of $88.2 \%$ (AUC 0.975 ). Several previous studies with the eGFR gold standard obtain higher cut-off values $(125 \mathrm{ng} /$ $\mathrm{mL} ; 142.3 \mathrm{ng} / \mathrm{mL} ; 163 \mathrm{ng} / \mathrm{mL}$ ) compared to this study. ${ }^{16}$ Whereas a previous study that focuses on the correlations between uromodulin and uACR showed that the higher uACR level is, the lower the uromodulin level. ${ }^{11}$ Uromodulin is not affected by age, sex, diet, muscle mass, infection, and inflammatory process. Therefore, the reason for differences in the serum uromodulin level could be due to the study population and the total study sample used. A lower cut-off value 
will lead to increased sensitivity and decreased specificity. The cut-off value established in this study is $47.2 \mathrm{ng} / \mathrm{mL}$ with a sensitivity of 93.3\% and a specificity of $88.2 \%$ (AUC 0.975), indicating that serum uromodulin can be used as a screening test for early markers of diabetic nephropathy.

Table 4 shows that there are 2 of 17 (11.76\%) subjects with normoalbuminuria who yield a serum uromodulin level less than $47.2 \mathrm{ng} /$ mL. Decreased eGFR indicates that the kidney function measured decreases before the albuminuria develops. ${ }^{17}$ Whereas in normal eGFR, decreased uromodulin level may be a biological marker that can uniquely identify the condition of diabetic nephropathy. ${ }^{16}$ Decreased kidney functions can develop temporarily when the urine albumin level regresses, so that a decline in the serum uromodulin level will be observed without albuminuria. ${ }^{17}$

There are 3 of 45 subjects with albuminuria whose serum uromodulin level is more than $47.2 \mathrm{ng} / \mathrm{mL}$. A previous study has reported that reduction in total nephron mass is seen in the early stage diabetic nephropathy, but the amount of uromodulin secreted by each functioning nephron increases(compensatory). ${ }^{15}$ Another study demonstrates that serum uromodulin has a negative correlation with eGFR, which is associated with the phenomenon that the uromodulin level measured in blood does not always reflect the amount of uromodulin in renal interstitium because uromodulin binds with various immune cells. ${ }^{18}$

There are several limitations in this study. First, the subjects did not really know the type of drugs that they consumed. Second, the activities and blood pressure were not measured during sampling. The third limitation is that the distribution between subjects with normoalbuminuria or albuminuria is not equal. Last but not least, there is a limitation from the fact that even though blood pressure affects urine albumin level, the urine albumin level is only checked once; hence, this does not follow the diagnostic criteria of diabetic nephropathy of at least two examinations in a period of 3-6 months.

To conclude, serum uromodulin level to uACR gold standard has good sensitivity and specificity that support its validity. The cut-off value for serum uromodulin level for diabetic nephropathy screening is $47.2 \mathrm{ng} / \mathrm{mL}$. The examination of serum uromodulin level can be used as an alternative of uACR test as a screening test of early marker of diabetic nephropathy.
Examination of serum uromodulin level can yield another diagnostic value; thereby reducing uncertainty in diagnosing diabetic nephropathy.

\section{References}

1. WHO. Classification of Diabetes Mellitus 2019. World Health Organization. 2019. p. 6-7.

2. Luiza M, Caramori A, Rossing P. Chapter 54 - diabetic nephropathy. Seventh Ed. Vol. 5, Endocrinology: Adult \& Pediatric. Elsevier; 2018. p. 934-57.

3. Gluhovschi C, Gluhovschi G, Petrica L, Timar $\mathrm{R}$, Velciov S, Ionita I, et al. Urinary biomarkers in the assessment of early diabetic nephropathy. J Diabetes Res. 2016;1-13.

4. Alicic RZ, Rooney MT, Tuttle KR. Diabetic kidney disease: Challenges, progress, and possibilities. Clin J Am Soc Nephrol. 2017;12(12):2032-45.

5. Kidney Disease: Improving Global Outcomes (KDIGO) CKD Work Group. KDIGO 2012 clinical practice guideline for the evaluation and management of Chronic Kidney Disease. Kidney Int Suppl. 2013;3(1):1-163.

6. Chevalier RL. The proximal tubule is the primary target of injury and progression of kidney disease: Role of the glomerulotubular junction. Am J Physiol Ren Physiol. 2016; 311(1):145-61.

7. Tramonti G, Kanwar YS. Review and discussion of tubular biomarkers in the diagnosis and management of diabetic nephropathy. Endocrine. 2013;43(3):494503.

8. Papadopoulou-Marketou N, KanakaGantenbein C, Marketos N, Chrousos GP, Papassotiriou I. Biomarkers of diabetic nephropathy: A 2017 update. Crit Rev Clin Lab Sci. 2017;54(5):326-42.

9. PERKENI. Konsensus Pengelolaan dan Pencegahan Diabetes Melitus Tipe 2 Di Indonesia. PB. Perkeni; 2015. p. 1-79.

10. Devuyst O, Olinger E, Rampoldi L. Uromodulin: From physiology to rare and complex kidney disorders. Nat Rev Nephrol. 2017;13(9):525-44.

11. Halankar A, Shalia K. Uromodulin levels in chronic kidney disease. Int J Biomed Adv Res. 2016;8:383-7.

12. Vaidya SR. Chronic renal failure. Sci Basis Urol Second Ed. 2019;2:1-14.

13. AlFehaid A. Prevalence of microalbuminuria and its correlates among diabetic patients 
attending diabetic clinic at National Guard Hospital in Alhasa. J Fam Community Med. 2017;24(1):1.

14. George JA, Gounden V. Novel glomerular filtration markers. Adv Clin Chem. 2019; 88:91-119.

15. El-Achkar TM, Wu XR. Uromodulin in kidney injury: An instigator, bystander, or protector? Am J Kidney Dis. 2012;59(3):452-61.

16. Steubl D, Block M, Herbst V, Nockher WA, Schlumberger W, Satanovskij R, et al. Plasma uromodulin correlates with kidney function and identifies early stages in chronic kidney disease patients. Med J. 2016;95(10):1-9.

17. Ibrahim AA, Baban RS, Khudair MS. Clinical and biochemical association between serum and urin level of the uromodulin protein with albuminuria in patients with type-2 diabetes mellitus. Biochem Cell Arch. 2019;19:236770.

18. Prajczer S, Heidenreich U, Pfaller W, Kotanko $P$, Lhotta $K$, Jennings $P$. Evidence for a role of uromodulin in chronic kidney disease progression. Nephrol Dial Transplant. 2010; 25(6):1896-903. 